REKOGNISI: Jurnal Pendidikan dan Kependidikan

ISSN 2527-5259 Vol.1, No.1, Desember 2016

\title{
PENERAPAN MODEL PEMBBLLAJARAN TALKING STICK UNTUK MENINGKATKAN MOTIVASI BELAJAR SISWA
}

\author{
Layil Safitri \\ PGSD Universitas Nahdlatul Ulama Sumatera Utara \\ Email:layildikdas@yahoo.com
}

\begin{abstract}
ABSTRAK
Penelitian ini bertujuan untuk mengetahui, dengan penerapan model pembelajaran talking stick dapat meningkatkan motivasi belajar siswa pada pelajaran IPA materi pokok Gaya di kelas IV SD Negeri 107415 Tanjung Sari Kec. Batangkuis T.P 2012/2013. Subjek penelitian ini sebanyak 35 orang. Dalam mencapai tujuan tersebut digunakan penelitian tindakan kelas dengan dua siklus. Setiap siklus ada dua pertemuan. Instrumen yang digunakan adalah lembar observasi motivasi belajar siswa. Hasil penelitian menunjukkan ada peningkatan dari siklus I hingga Siklus II, motivasi belajar tinggi dari 48,57\% menjadi 91,4\%. Keaktifan siswa ketika pembelajaran IPA dengan materi gaya meningkat. Dapat disimpulkan bahwa penerapan model pembelajaran Talking Stick dapat meningkatkan motivasi belajar siswa pada pelajaran IPA di Kelas IV SD Negeri 107415 Tanjung Sari.
\end{abstract}

Kata kunci : motivasi, model pembelajaran talking stick 


\begin{abstract}
This study aims to determine that the application of taling stick learning model can increase the students' learning motivation on IPA lesson which the subject matter is Gaya in fourth grade SD Negeri 107415 Tanjung Sari Kec. Batangkuis T.P 2012/2013. This research subject as many as 35 people. In achieving these objectives used the classroom action research with two cycles. Every cycle consists of two meetings. The instruments used were observation sheet of students' learning motivation. The results showed that three is an improvement from the first cycle to the second cycle, the high learning motivation from 48,57 percent to 91,4 percent. Student activity increased when learning IPA with "Gaya" material. It can be concluded that the application of talking stick learning models can increase the students' motivation on IPA lesson in fourth grade in SD Negeri 107415 Tanjung Sari.
\end{abstract}

Key words: motivation, talking stick learning model

\title{
PENDAHULUAN
}

Motivasi belajar merupakan salah satu faktor yang menentukan keberhasilan siswa dalam mecapai hasil belajar yang baik. Motivasi belajar yang ada dalam diri siswa bisa disebabkan beberapa faktor diantaranya dari lingkungan yaitu guru, orang tua, teman sebaya, model pembelajaran yang menyenangkan dan bervariasi.

Motivasi adalah dorongan dasar yang menggerakkan seseorang bertingkah laku. Motivasi dipandang sebagai dorongan mental yang menggerakkan dan mengarahkan perilaku manusia, termasuk perilaku belajar. Motivasi merupakan suatu keadaan atau kondisi yang mendorong, merangsang atau menggerakkan seseorang untuk melakukan sesuatu atau kegiatan yang dilakukan untuk mencapai tujuannya.

Motivasi dan belajar merupakan dua hal yang saling mempengaruhi. Ciriciri siswa yang memiliki motivasi belajar adalah tekun menghadapi tugas (dapat bekerja terus menerus dalam waktu yang lama dan tidak pernah berhenti sebelum selesai), ulet menghadapi kesulitan (tidak lekas putus asa), menunjukkan minat terhadap bermacam-macam masalah, lebih senang bekerja mandiri, cepat bosan pada tugas-tugas yang rutin, dapat mempertahankan pendapatnya (kalau sudah yakin akan sesuatu), tidak mudah melepaskan hal yang diyakini itu, senang mencari dan memecahkan masalah soal-soal.

Berdasarkan analisis data pada observasi awal (sebelum ada tindakan) hanya 7 orang siswa yang memiliki motivasi belajar tinggi yakni hanya 20\% dari 35 orang jumlah siswa. Siswa tidak memberikan peerhatian ketika guru menjelaskan materi pelajaran, siswa ketika dihadapkan pada masalah-masalah yang sedikit rumit akan cepat menyerah dan sama sekali tidak mau memberi solusi ataupun 
pendapat, kurangya keberanian siswa dalam mengungkapkan pendapat, mereka selalu menutup mulut tidak mau berbicara.

Pembelajaran IPA di SD yang masih disajikan secara verbal melalui kegiatan ceramah dan text book oriented diindikasi timbulnya rendahnya motivasi belajar siswa. Siswa juga beranggapan bahwa IPA adalah pelajaran yang sulit untuk dipahami dan membosankan. Sebagian siswa yang dapat mengikuti pelajaran dengan baik dan sebagian siswa tidak berminat dalam belajar, tidak dapat memberikan perhatian dalam belajar, dan tidak terampil dalam mengikuti pelajaran dengan baik sehingga berdampak pada penurunan hasil belajar siswa.

Mengatasi masalah yang dihadapi oleh siswa kelas IV dalam pembelajaran IPA diperlukan suatu model pembelajaran yang membuat siswa aktif, merasakan atmosfer kelas yang menyenangkan sehingga motivasi belajar IPA siswapun meningkat. Salah satu model pembelajaran yang dimaksud adalah talking stick.

Model pembelajaran talking stick dapat diartikan sebagai model pembelajaran bermain tongkat yaitu pembelajaran yang dirancang untuk mengukur tingkat penguasaan materi pelajaran, menumbuhkan motivasi belajar dan menciptakan suasana belajar yang menyenangkan bagi siswa dengan menggunakan media tongkat. Agus Suprijono (2009:109) "Pembelajaran dengan model talking stick mendorong peserta didik untuk berani mengemukakan pendapat". Jadi model pembelajaran talking stick merupakan suatu cara yang efektif untuk mendorong siswa melaksanakan praktek pembelajaran secara aktif dan menyenangkan.

Rumusan masalah yang akan diteliti dari penelitian ini adalah "Apakah dengan menerapkan model pembelajaran talking stick dapat meningkatkan motivasi belajar siswa pada pelajaran IPAdi Kelas IV SD Negeri 107415 Tanjung Sari Kec. Batangkuis T.P 2012/2013?. Sejalan dengan rumusan maslah ini, tujuan penenlitian ini adalah untuk mengetahui apakah dengan menerapkan model pembelajaran talking stick dapat meningkatkan motivasi belajar siswa pada pelajaran IPA di Kelas IV SD Negeri 107415 Tanjung Sari Kec. Batangkuis T.P 2012/ 2013.

\section{METODE PENELITIAN}

Jenis penelitian ini adalah penelitian tindakan kelas (classroom Action Research), penelitian ini menggunakan model pembelajaran talking stick, penelitian ini di SD Negeri 107415 Tanjung Sari Kec. Batangkuis T.P 2012/2013. Subyek dalam penelitian ini adalah seluruh siswa kelas IV SD Negeri 107415 Tanjung Sari Kecamatan Batangkuis T.P 2012/2013

Adapun prosedur penelitian ini meliputi kegiatan pelaksanaan PTK secara garis besar terdiri dari empat tahap. Keempat tahap dalam penelitian ini 
merupakan unsur untuk membentuk sebuah siklus. Pelaksanaan penelitian ini direncanakan 2 siklus dan dalam setiap siklus ada 2 kali pertemuan.

Hasil skor motivasi siswa dihitung dalam bentuk persentase, dengan formula sebagai berikut:

$$
P P H=\frac{B}{N} \times 100 \%
$$

Keterangan:

PPH : Persentase Penilaian Hasil

B : Skor Yang Diperoleh Siswa

$\mathrm{N}$ : Skor Total

Mengukur variabel kreativitas belajar siswa secara klasikal dapat dirumuskan :

$$
P=\frac{f}{n} X 100 \%
$$

Keterangan:

$P$ : Angka Persentase

$\mathrm{f}$ : Jumlah siswa yang mengalami perubahan

$\mathrm{n}$ : Jumlah seluruh siswa

\section{HASIL DAN PEMBAHASAN}

\section{Siklus I}

\section{Perencanaan}

Pada tahap perencanaan ini yang dilakukan adalah merencanakan tindakan yang akan dilakukan sebagai awal penelitian yaitu berupa skenario dalam pembelajaran. Kegiatan yang dilakukan pada tahap ini antara lain: a) menyusun rencana pelaksanaan pembelajaran untuk setiap pertemuan dengan menerapkan model pembelajaran talking stick; b) menyusun daftar pertanyaan untuk siswa sesuai materi pokok; c) membuat tongkat yang di balut oleh pertanyaan untuk siswa; d) menyusun lembar pedoman observasi pelaksanaan pembelajaran selama penerapan tindakan penelitian.

2. Pelaksanaan

a. Kegiatan Awal

Kegiatan yang dilaksanakan antara lain kesiapan kelas dalam pembelajaran (absensi, kebersihan kelas), siswa berdoa sebelum memulai pembelajaran, siswa mempersiapkan diri untuk memulai pelajaran, siswa mencermati contoh kasus yang disampaikan oleh guru, guru memotivasi siswa, memberitahukan tujuan pembelajaran pada siswa. 
b. Kegiatan inti

Kegiatan yang dilaksanakan antara lain siswa mencermati penjelasan guru mengenai materi Gaya, guru membimbing siswa mengerjakan latihan sesuai materi yang telah disampaikan, guru membimbing siswa membentuk kelompok heterogen yang terdiri dari enam orang setiap kelompok, guru memberi penjelasan mengenai aturan permainan talking stick pada siswa, guru memberikan tongkat berbalut soal yang telah di siapkan sebelumnya, kelompok pertama menerima tongkat dari guru kemudian sambil mendengarkan musik tongkat diberikan secara bergilir dari satu kelompok ke kelompok berikutnya, kelompok yang memegang tongkat tepat saat musik berhenti, maka kelompok tersebut harus menjawab soal yang terdapat pada tongkat, begitu seterusnya hingga soal pada tongkat habis.

c. Kegiatan Akhir

Siswa menyimpulkan materi pelajaran yang telah disampaikan oleh guru. Memberi tugas rumah guna mempersiapkan materi yang akan datang.

\section{Pengamatan}

Observasi dilaksanakan selama proses pembelajaran berlangsung. Selama pembelajaran IPA yang dilakukan dengan dua pertemuan membuat siswa mulai memperhatikan guru ketika menjelaskan pola pembelajaran IPA yang akan dilakukan. Siswa berusaha mengikuti arahan dari guru ketika pembelajran IPA. Siswa mulai berani untuk bertanya.

\section{Refleksi}

Kegiatan refleksi ini merupakan pedoman mengajar yang dilakukan untuk tahap selanjutnya. Pembelajaran yang dilakukan selama dua pertemuan belum memberikan hasil yang baik untuk motivasi belajar siswa. Siswa belum aktif dan takut untuk bertanya.

\section{Siklus II}

\section{Perencanaan}

Prosedur tahap pembelajaran ini dilakukan untuk memperbaiki kekurangan yang ditemukan pada siklus I. Adapun kegiatan yang dilakukan pada tahap ini yaitu menyusun rencana pelaksanaan pembelajaran untuk setiap pertemuan dengan menerapkan model pembelajaran talking stick, menyusun daftar pertanyaan untuk siswa sesuai materi pokok, membuat tongkat yang di balut oleh pertanyaan untuk siswa, menyusun lembar pedoman observasi pelaksanaan pembelajaran selama penerapan tindakan penelitian.

2. Pelaksanaan

Pada tahap ini peneliti melaksanakan rencana pembelajaran yang telah direncanakan berupa proses pembelajaran yang disesuaikan dengan refleksi pada siklus I. Kegiatan yang dilakukan, yaitu: 
a. Kegiatan Awal

Kegiatan yang dilakukan antara lain kesiapan kelas dalam pembelajaran (absensi, kebersihan kelas), siswa berdoa sebelum memulai pembelajaran, siswa mempersiapkan diri untuk memulai pelajaran, siswa mencermati contoh kasus yang disampaikan oleh guru, guru memotivasi siswa, dan memberitahukan tujuan pembelajaran pada siswa.

b. Kegiatan inti

Kegiatan yang dilakukan antara lain: siswa mencermati penjelasan guru mengenai materi Gaya, guru membimbing siswa mengerjakan latihan sesuai materi yang telah disampaikan, guru membimbing siswa membentuk kelompok heterogen yang terdiri dari enam orang setiap kelompok, guru memberi penjelasan mengenai aturan permainan talking stick pada siswa, guru memberikan tongkat berbalut soal yang telah di siapkan sebelumnya, kelompok pertama menerima tongkat dari guru kemudian sambil mendengarkan musik tongkat diberikan secara bergilir dari satu kelompok ke kelompok berikutnya, kelompok yang memegang tongkat tepat saat musik berhenti, maka kelompok tersebut harus menjawab soal yang terdapat pada tongkat.

c. Kegiatan Akhir

Pada akhir pembelajaran siswa menyimpulkan materi pelajaran yang telah disampaikan oleh guru. Guru memberikan tindak lanjut dengan memberi tugas rumah guna mempersiapkan materi yang akan datang.

\section{Pengamatan}

Pada siklus II ini tahap pengamatan dilakukan untuk mengetahui sejauh mana pelaksanaan tindakan terhadap perubahan tingkat motivasi belajar siswa dengan kondisi yang diberikan.

2. Refleksi

Pada siklus II hasil motivasi siswa sudah meningkat dan memenuhi indikator keberhasilan. Oleh karena itu, tindakan yang dilakukan berakhir pada siklus II.

Melalui penggunaan model pembelajaran talking stick pada mata pelajaran IPA materi pokok "Gaya"di kelas IV SD Negeri No. 107415 Tanjung Sari T.P 2012/2013 telah terbukti motivasi belajar siswa meningkat baik secara individual maupun secara klasikal. Pada siklus II pertemuan I motivasi belajar siswa mengalami peningkatan secara klasikal yaitu terdapat 24 orang siswa yang memiliki motivasi belajar dengan kriteria baik dan sangat baik atau berkisar 68,6\%. Berdasarkan kesimpulan sementara bahwa motivasi balajar siswa pada mata pelajaran IPA materi pokok "Gaya" mengalami sedikit peningkatan namun belum sesuai dengan harapan sehingga perlu perbaikan dan pengembangan pembelajaran yang lebih sistematis pada siklus II pertemuan ke II. 
Ternyata setelah dilakukan perbaikan pembelajaran dengan menggunakan model pembelajaran talking stick siswa lebih semangat sehingga siswa lebih termotivasi dalam belajar. Pada tindakan Siklus II, merupakan perbaikan pembelajaran pada siklus I. Skor rata-rata kelas yang diperoleh pada siklus II ini meningkat dari siklus sebelumnya.

Hasil observasi pada siklus II pertemuan I secara klasikal dengan skor rata-rata 91,4\%. Rata-rata kelas dapat dikatakan bahwa tingkat motivasi belajar yang diperoleh dari lembar observasi motivasi belajar siswa kelas IV SD Negeri No. 107415 Tanjung Sari sangat baik. Untuk lebih jelasnya, data yang diperoleh dapat dilihat pada grafik tentang rata-rata kelas saat siklus I pertemuan I dan II, dan siklus II pertemuan I dan II. Grafik tersebut adalah seperti gambar 1 berikut:

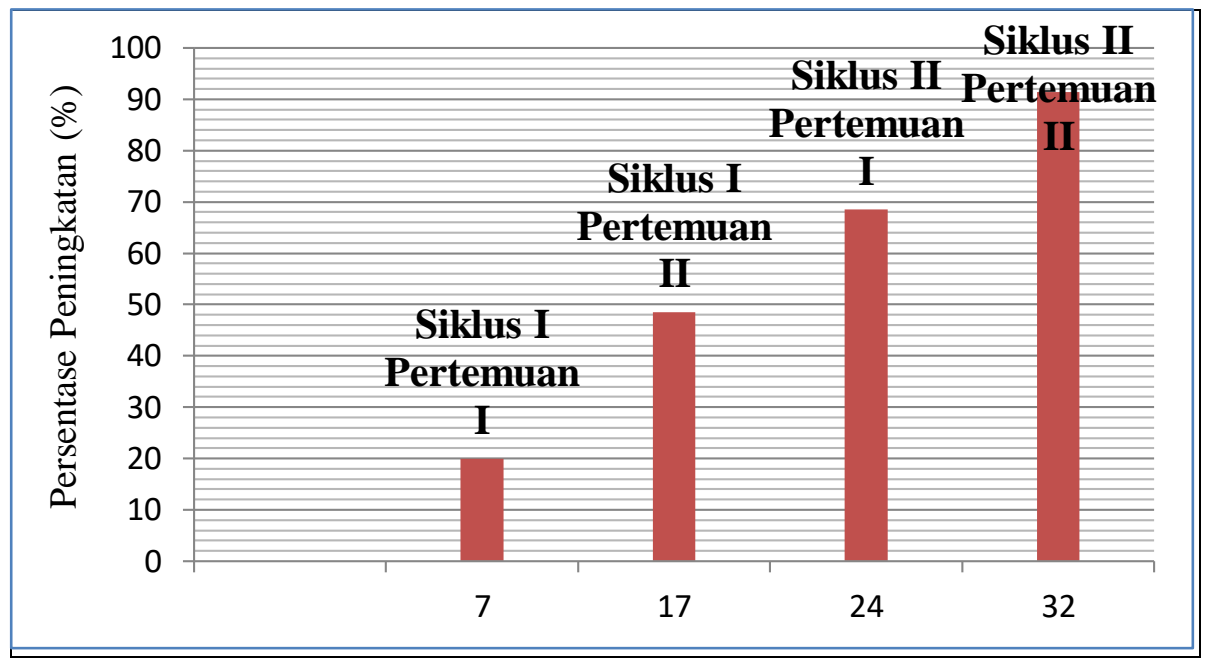

\section{Gambar 1. Rata-Rata Kelas Siklus I dan Siklus II}

\section{SIMPULAN}

Pembelajaran dengan menggunakan model pembelajaran talking stick dapat meningkatkan motivasi belajar siswa dalam mata pelajaran IPA materi pokok Gaya (hipotesis diterima). Siswa lebih aktif dan kreatif dalam kelas ketika pembelajaran IPA menggunakan model pembelajaran talking stick. 
Penerapan Model Pembelajaran Talking Stick ... -Layil Safitri

\section{DAFTAR PUSTAKA}

Dewi, R. 2010. Penelitian Tindakan Kelas. Medan: Pasca Sarjana Unimed.

Djamarah, S.B. 2011. Psikologi Belajar. Jakarta: Rineka Cipta.

Hamdani. 2011. Strategi Belajar Mengajar. Bandung: Pusataka Setia.

Isjoni. 2009. Pembelajaran Kooperatif. Yogyakarta: Pustaka Pelajar.

Istarani. 2011. 58 Model Pembelajaran Inovatif. Medan: Media Persada.

Maheswara. 2012. Cara Cespleng Cepat Hafal semua Materi IPA SD. Jakarta: Gramedia.

Panut, dkk. 2006. Dunia IPA 4B. Jakarta: Yudhistira.

Sardiman, A.M. 2011. Interaksi \& Motivasi Belajar Mengajar. Jakarta: Rajawali Pers.

Suprijono, A. 2010. Cooperative Learning Teori dan Aplikasi PAIKEM. Yogyakarta: Pustaka Pelajar.

Trianto, 2010. Mendesain Model Pembelajaran Inovatif-Progresif. Jakarta: Kencana. 